Review Article

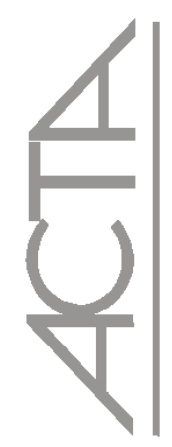

\title{
Acute and chronic pain: a narrative review of the literature
}

\author{
Dor aguda e crônica: revisão narrativa da literatura
}

Dolor agudo y crónico: revisión narrativa de la literatura

Ana Maria Calil Sallum¹, Dayse Maioli Garcia², Mariana Sanches ${ }^{3}$

\begin{abstract}
The study objectives were to identify the organic, emotional and psychic prevalent consequences in patients with acute and chronic pain and punctuate the main assessment tools for these pains. A narrative review of the literature was conducted using descriptors related to pain measurement, signs and symptoms, totalizing 184 articles. The electronic databases MEDLINE and LILACS were searched from January 2000 to December 2010. The review pointed out a series of conclusive studies about the organic repercussions more frequent in acute and chronic pain conditions and the use of different rating scales for both situations. It is believed that these findings could be of great values for health teams, could contribute with a better practice and with customer satisfaction in the hospital scenario and at home.
\end{abstract}

Keywords: Pain measurement; Nursing care; Signs and symptoms; Quality of healthcare.

\section{RESUMO}

Os objetivos do estudo foram identificar as repercussões orgânicas, emocionais e psíquicas prevalentes em pacientes com dor aguda e dor crônica e pontuar os principais instrumentos de avaliação para essas dores. Foi realizada uma revisão narrativa da literatura, utilizando-se descritores relacionados a medição da dor, cuidados de enfermagem, sinais e sintomas, totalizando 184 artigos. As bases eletrônicas pesquisadas foram LILACS e MEDLINE, entre janeiro de 2000 a dezembro de 2010. Esta revisão pontuou uma série de estudos conclusivos sobre as repercussões orgânicas mais freqüentes nos quadros álgicos agudos e crônicos e o uso de escalas de avaliação distintas para ambas as situações. Acredita-se que esses achados possam ser de grande valia para as equipes de saúde, contribua com melhores práticas e satisfação do cliente nos cenários intra hospitalar e domiciliário.

Descritores: Medição da dor; Cuidados de enfermagem; Sinais e sintomas; Qualidade da assistência à saúde

\section{RESUMEN}

Los objetivos del estudio fueron identificar las repercusiones orgánicas, emocionales y psíquicas prevalentes en pacientes con dolor agudo y dolor crónico y puntuar los principales instrumentos de evaluación para esos dolores. Se realizó una revisión narrativa de la literatura, utilizándose descriptores relacionados a la medición del dolor, cuidados de enfermería, signos y síntomas, en un total de 184 artículos. Las bases electrónicas investigadas fueron LILACS y MEDLINE, entre enero de 2000 a diciembre de 2010. Esta revisión puntuó una serie de estudios conclusivos sobre las repercusiones orgánicas más frecuentes en los cuadros álgicos agudos y crónicos y el uso de escalas de evaluación distintas para ambas situaciones. Se cree que esos hallazgos podrán ser de gran valía para los equipos de salud y que contribuya con mejores prácticas y satisfacción del cliente en los escenarios intra hospitalario y domiciliario.

Descriptores: Dimensión del dolor; Atención de enfermería; Signos y síntomas; Calidad de la atención de salud

\footnotetext{
${ }^{1}$ Post Doctorate in Nursing. Consultant of the Sociedade Beneficente de Senhoras - Hospital Sirio-Libanês in the area of pain and research in nursing - São Paulo (SP), Brazil.

${ }^{2}$ Master's degree in Nursing. Nurse of the pain service at the Sociedade Beneficente de Senhoras - Hospital Sirio-Libanês - São Paulo (SP), Brażil.

${ }^{3}$ Pain specialist. Nurse of the pain service at the Sociedade Beneficente de Senhoras - Hospital Sirio-Libanês - São Paulo (SP), Brażil.
} 


\section{INTRODUCTION}

Pain is a common event in many scenarios involving healthcare, from birth to death, in the hospital or outside of $\mathrm{it}^{(1,2)}$.

Based on this reality, the teaching of pain and other aspects related to this phenomenon should be a common practice in undergraduate courses in the area of health. However, reality shows that ignorance on this subject constitutes one of the main obstacles to its proper evaluation, treatment and control of pain $^{(1-3)}$.

Assisting a person with pain involves - from the point of view of both the caregiver and the one being cared for - attention in many aspects such as cultural, affective, emotional, educational, psychological, environmental, religious and cognitive, which can make the process more or less prickly ${ }^{(4,5)}$. The lack of these elements certainly complicates the assistance and the relationship between the observer and the experience of phenomenon of pain.

In professional practice the quest for scientific knowledge should be a North craved every day, ethics a pillar for guiding the actions in nursing and quality a target to be achieved by all the individuals involved directly or indirectly with assistance ${ }^{(6)}$. Within this perspective the relief of pain, the pursuit of quality and risk minimization constitute a great challenge for all the committed professionals who are aware of their role in a healthcare team.

The absence of objective instruments to assess pain in clinical practice or mistakes that may arise from an underestimation and undertreatment can jeopardize the quality of assistance and contribute with morbidity and increased time of hospitalization ${ }^{(7)}$.

In our professional journeys as clinical nurses, researchers and teachers we often question ourselves what would the anguishes of health professionals be like, when faced with a patient with non-relieved pain? What are the best ways for assessment and treatment? How could they recognize the presence of signs and symptoms of pain presence?

The main motivation for conducting this review was a result of three factors: the focus of the subject pain and analgesia in graduate schools of Nursing, the practical need of these thematic in any health scenario and the increasing interest for the theme identified by the authors during their academic, hospital and research practice over the last 15 years.

This study aims to answer some questions and contribute with a better professional practice related to the theme pain.

\section{OBJECTIVES}

Identify the prevalent organic, emotional and psychic effects in patients with acute and chronic pain.

Rate the main instruments of assessment of acute and chronic pain used in clinical practice.

\section{METHODS}

It is a study of narrative review of the literature. Narrative reviews are extensive publications appropriate to describe and discuss the development or "state of the art" of a particular subject, from a theoretical or contextual point of view. They basically constitute an analysis of the literature published in books, in printed or electronic magazines, with the interpretation and personal critical analysis of the authors. This category of articles has a critical role for continuing education as it allows the reader to acquire and update knowledge about a specific theme in a short period of time ${ }^{(8)}$.

The survey questions were: What are the most common organic effects in patients with acute and chronic pain? Would there be specific and/or more adequate instruments to assess it?

The search for articles included research in electronic databases and manual search of citations in the publications initially identified. The electronic database researched were LILACS (Latin American and Caribbean Literature in Health Sciences - Literatura Latino Americana e do Caribe em Ciências de Saúde), and International Literature in Health Sciences (MEDLINE). In MEDLINE database a keyword in English was used, while in LILACS keywords used were in Portuguese, English and Spanish. The covered period was between January/2000 and December/2010.

For the articles search we used the descriptors standardized by the Health Science Descriptors, namely: pain measurement; care in nursing and signs and symptoms. To refine the search the following terms were added to these combinations: classification; epidemiology; prevention; control; causalgia and evaluation. In the end, there were 434 combinations among the descriptors to obtain the maximum of references possible.

The titles and abstracts of all the articles identified in the electronic search were reviewed. Whenever possible, the studies that seemed to fulfill the criteria of inclusion were obtained in full.

Based on this action, it was created a list of articles to be included in the study. The abstracts were compiled and directed according with the objectives for the construction of the article. 
Inclusion criteria were: to be a research article, a case study and systematic reviews in journals about pain, pain assessment, painful repercussions, assessment of pain in the postoperative period, oncological and non-oncological chronic pain, assistance humanization, chronic disease and nursing in which there were data about organic, emotional and psychic prevalent repercussions in patients with acute and chronic pain and/or that punctuated the main assessment tools for these pains.

\section{RESULTS}

In MEDLINE database, during the period between 2000 and 2010, 326 articles that met the inclusion criteria were identified and 108 were selected. To this total of 108 articles, 76 found in LILACS database were added, totalizing 184 articles that met the inclusion criteria.

The main reasons for excluding the articles were: describing the pharmacological action of the treatment, describing actions or a lack of them when faced with the pain phenomenon, involving ethical questions or not including the description of the main signs and symptoms related to acute/chronic pain or the description of instruments to assess pain.

Of the 184 articles analyzed, 74 of the studies present cross-sectional design, 86 present retrospective data analysis, both with quantitative approach and 24 studies present cross-sectional design with qualitative approach. Among the selected studies, 54 discussed the use of scales, 75 discussed, besides the use of scales, some aspect related to pain complaint and its impacts and 55 presented signs and symptoms related to acute or chronic pain. Studies originating from the five continents were found, with highlights to North American, Brazilian and European publications. Regarding Brazil, stood out the studies about pain from four research centers, two led by nurses and two led by physicians, all in the Southeast region.

\section{DISCUSSION}

Considering that this is a narrative review of the literature, this research is limited in highlighting the importance of an adequate choice of instruments for measurement or assessment of pain as a subjective way of understanding the impacts in the evolution of the patient, responding to some questions and contributing with a better professional practice related with the theme.

The studies are unanimous in pointing out that the main effects arising from acute pain, related to its nonrelief, are associated with neurovegetative alterations such as: tachycardia, arrhythmias, decreased oxygen saturation and oxygen delivery to tissues, restlessness, sweating, increased cardiac work, increased blood pressure, risk of bleeding, increased muscle contraction, anxiety and fear; as major complicators: decreased sleep, loss or decreased appetite, dehydration, difficulty in walking, difficulty in moving around in bed, difficulty to breathe deeply due to the decrease in chest expansion (shallow breathing), cough difficulty, increase in length of hospitalization, increased cortisol levels, increased risk of thromboembolic and infectious processes ${ }^{(7,9-12)}$.

"Pain is defined as an unpleasant sensory and emotional experience, associated with a tissue damage or potential or described in terms of such damage" (7). Acute pain begins with a lesion or an injury and algogenic substances are locally synthesized and released, stimulating nerve terminations (noniceptors) of thin myelinated or unmyelinated fibers; its natural evolution is the remission. However, due to the activation of several neuronal pathways during a long period of time, the character of pain may change and the acute pain can become chronic ${ }^{(1,7,9,10)}$.

Literature points out as the triggering factors of these problems: sub treatment of pain, its undervaluation, the reduced use of opioids, inadequate training of health professionals on pain and medication phenomena, erroneous beliefs and values regarding pain and analgesia, the difficulty to assess pain or no systematic evaluation ${ }^{(3,13-14)}$.

Regarding the origin of acute pain, the majority of studies analyzes its effects in the postoperative period, which also involves inflammatory or infectious processes, followed by pain resulting from trauma and burns, the latter concentrated in two authors in the national scene $e^{(13,15)}$.

As for the use of scales for acute pain assessment, stand out the numerical scale (0 to 10$)$, the visual analogue scale, the verbal descriptor scale (no pain/mild pain/moderate pain/severe pain/unbearable pain) and the body chart ${ }^{(16-17)}$. Like any assessment tool, the scales mentioned above have limitations and prioritize the assessment of pain intensity (one-dimensional), which in hospital practice is the most measured aspect and will often determine the analgesic treatment.

For children there are the Cebolinha Faces Scale and the Wong-Baker Faces Pain Rating Scale, the Neonatal Infant Pain Scale (NIPS) and the Face, Legs, Activity, Cry, Consolability (FLACC). The scales used in pediatrics seek to identify (indirectly) the emotional state of the child, such as the Cebolinha Faces and the Wong-Baker, while the NIPS (used for newborns) and the FLACC, suitable for children up to 4 years, have objective indicators of assessment related to behavior ${ }^{(18-22)}$. Literature indicates the importance of the participation of parents and/or caregivers in this assessment and the permanence of them together with the children ${ }^{(18-20)}$. 
Faced with chronic pain, great part of the studies is related to cancer and chronic pain of neuropathic origin, although a patient with cancer can show acute pain conditions that are in the majority of cases, related with the treatment such as chemotherapy, radiotherapy, surgeries, biopsies, among others ${ }^{(23-25)}$.

Unlike acute pain, chronic pain is not related with the permanence nor the emergence of neurovegetative amendments (warning signs). Chronic pain is more than a symptom, it is a disease that persists; it does not vanish after the injury heals or is related to chronic pathologic processes $^{(24)}$. Literature points the duration of pain as a period of three months or more ${ }^{(24-26)}$.

The constant presence of pain and its prolonged duration can be disruptive and cause alterations of physical activities, sleep, sex life, changes in mood, low self-esteem, negative or suicidal thoughts, hopeless appreciation of life and change relationships in family, work and leisure ${ }^{(25-26)}$.

The assessment of chronic pain is more complex compared to acute pain because it involves behavioral components (attitudes), as well as emotional, social, cognitive, beliefs, expectations, values, among other issues ${ }^{(27-29)}$.

Due to the magnitude of the theme it was made the choice of pointing the McGill questionnaire as an important instrument for the assessment of chronic pain and its impact. It is considered a good instrument to evaluate chronic pain and it is the most used to characterize and distinguish the affective, sensory and evaluative components when the objective is to obtain qualitative and quantitative information based on verbal descriptions. It is considered a universal instrument, able to standardize the language of pain and it was developed from a literature survey of 102 words used to describe pain ${ }^{(29-31)}$.

The questionnaire McGill also contains an intensity scale (0 to 10) and a body chart to represent the site of pain and characterize aspects as frequency and duration of pain complaint ${ }^{(29-30)}$.

It is important to point out that the evaluation of chronic pain requires a multidimensional analysis, and the option for either scale should be sustained by the real possibilities of practical clinical use.

In the area of chronic pain stands out the Inventory of Attitudes toward Pain - a brief version composed of seven domains of beliefs and attitudes when facing pain: medical cure, control, solicitude, disability, medication, emotion and physical damage ${ }^{(32)}$ and the Chronic Pain Self-Efficacy Scale for assessment of the self-efficacy of patients with chronic pain ${ }^{(27)}$.
Thus it is possible to state that in the evaluation of acute pain, aspects related to the injury conditions or the disease should be emphasized, such as location, appearance, evolution; the characteristics of pain such as start, location, intensity, quality, frequency, duration, evolution pattern, factors of worsening and improvement, associated symptoms, relief obtained after pharmacological and non-pharmacological conduct; neurovegetative responses of physical, emotional and behavioral nature as anxiety, psychomotor agitation, anger, hostility, among others, and the losses mentioned above.

In chronic pain stand out the assessment aspects in the following components: psychological, sociocultural, emotional state, personality and behavior changes (gains and losses), family, work and leisure relationships, beliefs, adherence to pharmacological treatment and to other non-pharmacological therapies ${ }^{(33)}$.

Although pain is a subjective phenomenon and the verbal response of the patient is a "golden standard" for the conducts to be adopted regardless the origin of pain, research shows similarities among findings of individuals with different sociocultural and disease history, whether by uni or multidimensional scales. This fact leads to the encouragement of its use in health institutions, aiming a better practice, research development and quality in assistance.

\section{CONCLUSION}

This review contributes to the understanding that the main effects related to acute pain are neurovegetative alterations indicative of warning signs, whereas in chronic pain the factors involved are emotional, cultural and psychic socio-affective, among others.

The evaluation of acute pain is simpler if compared to the evaluation of chronic pain and in clinical practice stand out the intensity of pain, neurovegetative alterations and measures related to pharmacological treatment. In chronic pain the use of multidimensional instruments is recommended as they allow the assessment of the matter of pain in a broader and more complex way.

Literature is emphatic in pointing out the subjectivity or experience of pain phenomenon, contraindicating standardizations or conduct generalization, whether in cases of acute or chronic pain.

National literature presents relevant production on the theme. However, further studies targeted to the elderly in our midst are recommended. 


\section{REFERENCES}

1. Pasero C, McCaffery M. The patient's report of pain: Believing vs. accepting. There's a big difference. Am J Nurs. 2001; 101(12):73-4.

2. McCaffery M, Grimm MA, Pasero C, Ferrell B, Uman GC. On the meaning of "drug seeking". Pain Manag Nurs. 2005; 6 (4):122-36.

3. Bernardo CL. Pain: the theme teaching in nursing graduation courses in southeasteam Brazil [dissertação]. São Paulo (SP): Universidade Federal de São Paulo;1999.

4. Kurita GP, Pimenta CA. [Compliance with chronic pain treatment: study of demographic, therapeutic and psychosocial variables]. Arq Neuropsiquiatr. 2003; 61(2B): 416-25. Portuguese.

5. Lima MA, Neves R, Sá S, Pimenta C. [Attitude of workers with chronic pain in different occupational activities: an approach of the cognitive-behaviorist psychology]. Ciên Saúde Coletiva. 2005;10(1):163-73. Portuguese.

6. Pires MR. [Politicity of care as an emancipatory reference for nursing: getting to know to care better, delivering care to confront, delivering care to emancipate]. Rev Latinoam Enferm. 2005; 13(5):729-36. Portuguese.

7. Department of Health and Human Services (US). National Institutes of Health. NIH Consensus Development Program. The integrated approach to the management of pain [Internet]. Consensus Development Conference Statement; 1986 May 19-21; Kensington(MD) [cited 2012 May]. Available from: http://consensus.nih.gov/1986/198 6PainManagement055html.htm.

8. Atallah NA, Castro AA. Revisão sistemática da literatura e metanálise: a melhor forma de evidência para tomada de decisão em saúde e a maneira mais rápida de atualização terapêutica [Internet] [citado 2005 Maio 15]. Disponível em: http://www.epm.br/cochrane.

9. Santos CM, Pimenta CA, Nobre MR. The PICO strategy for the research question construction and evidence search. Rev Latinoam Enferm. 2007;15(3): 508-11.

10. Teixeira MJ, Teixeira WGJ, Kraychete DC. Epidemiologia geral da dor. In: Teixeira MJ, Braum FHO, Marques JO, Lin T Y, organizadores. Dor: contexto interdisciplinar. Curitiba: Maio; 2003. p. 53-66.

11. Drummond JP. Dor aguda: fisiopatologia clínica e terapêutica. São Paulo: Atheneu; 2000. Capítulo 3, Dor pós-traumática; p. 57-71.

12. Bottega FH, Fontana RT. [Pain as the fifth vital sign: use of the assessment scale by nurses in general hospital]. Texto \& Contexto Enferm. 2010; 19(2):283-90. Portuguese.

13. Calil AM, Pimenta CA. Gravity of injury and analgesia in patients who suffered traffic accidents. Acta Paul Enferm. 2008; 21(3):398-403.

14. Garcia DM, Mattos-Pimenta CA. Pain centers professionals' beliefs on non-cancer chronic pain. Arq Neuropsiquiatr. 2008; 66 (2A): 221-8.

15. Pereira LV, Sousa FA. Psychophysical evaluation of the descriptors of pain in the postoperative. Rev Latinoam
Enferm. 2007;15 (3):474-9.

16. Nascimento LA, Kreling MC. Assessment of pain as the fifth vital sign: opinion of nurses. Acta Paul Enferm. 2011; 24(1): 50-4.

17. Andrade EV, Barbosa MH, Barichello E. Pain assessment in postoperative cardiac surgery. Acta Paul Enferm. 2010; 23(2):224-9.

18. Alves MM. Validação de uma escala para avaliação de dor em crianças brasileiras menores de cinco anos [dissertação]. Porto Alegre: Universidade Federal do Rio Grande do Sul; 2006.

19. Correia LL, Linhares MB. Assessment of the behavior of children in painful situations: literature review. J Pediatr (Rio J). 2008; 84(6):477-86.

20. Rossato LM, Magaldi FM. Multidimensional tools: application of pain quality cards in children. Rev Latinoam Enferm. 2006; 14(5):702-7.

21. Bueno M, Kimura AF, Pimenta CA. Pain assessment in neonates who underwent cardiac surgery. Acta Paul Enferm. 2007; 20(4):428-33.

22. Silva FC, Thuler LC. Cross-cultural adaptation and translation of two pain assessment tools in children and adolescents. J Pediatr (Rio J). 2008; 84(4):344-9.

23. Merskey H, Bogduk N, editors. Classification of chronic pain: descriptions of chronic pain syndromes and definitions of pain Terms. 2nd ed. Seattle: IASP Press; 1994.

24. Oliveira JT. [Behavioral aspects of chronic pain syndromes]. Arq Neuropsiquiatr. 2000; 58(2A):360-5. Portuguese.

25. Castro MM, Daltro C. Sleep patterns and symptoms of anxiety and depression in patients with chronic pain. Arq Neuropsiquiatr. 2009; 67(1):25-8.

26. Reis LA, Torres GV. [Influence of chronic pain in the functional capacity of institucionalized elderly]. Rev Bras Enferm. 2011; 64(2):274-80. Portuguese.

27. Salvetti MG, Pimenta CA. Chronic pain self-efficacy scale portuguese validation. Rev Psiquiatr Clín. 2005; 32(4):202-10.

28. Pedrosa DF, Pelegrin AK, Siqueira HB, Silva TC, Colhado OC, Sousa FA. Evaluation of the quality of life of clients with chronic ischemic pain. Rev Latinoam Enferm. 2011; 19(1):67-72.

29. Pimenta CA. Aspectos culturais, afetivos e terapêuticos relacionados à dor no câncer [tese]. São Paulo: Universidade de São Paulo, Escola de Enfermagem; 1995.

30. Pimenta CA, Teixeira MJ. [Adaptation of McGill questionnaire to portuguese language]. Rev Esc Enferm USP. 1996; 30(3):473-83. Portuguese.

31. Varoli FK, Pedrazzi V. Adapted version of the mcgill pain questionnaire to Brazilian Portuguese. Braz Dent J. 2006; 17(4):328-35.

32. Pimenta CA, Kurita GP, Silva EM, Cruz DA. Validity and reliability of the Survey of Pain Attitudes (SOPA-28 items) in the portuguese language. Rev Esc Enferm USP. 2009; 43(N Spec):1071-9.

33. Sousa FA, Pereira LV, Cardoso R, Hortense P. Multidimensional pain evaluation scale. Rev Latinoam Enferm 2010; 18(1):3-10. 